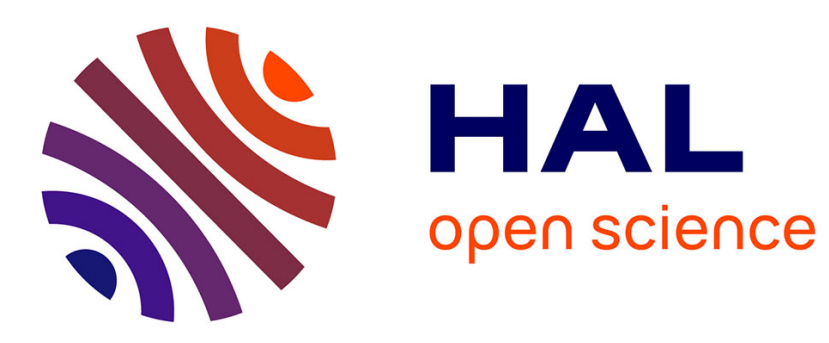

\title{
Italy: Still a Pro-European, but not a Fully Europeanised Elite?
}

Christophe Roux, Luca Verzichelli

\section{To cite this version:}

Christophe Roux, Luca Verzichelli. Italy: Still a Pro-European, but not a Fully Europeanised Elite? South European Society and Politics, 2010, 15 (1), pp.11-33. 10.1080/13608746.2010.496920 . hal02141745

\section{HAL Id: hal-02141745 \\ https://hal.umontpellier.fr/hal-02141745}

Submitted on 28 May 2019

HAL is a multi-disciplinary open access archive for the deposit and dissemination of scientific research documents, whether they are published or not. The documents may come from teaching and research institutions in France or abroad, or from public or private research centers.
L'archive ouverte pluridisciplinaire HAL, est destinée au dépôt et à la diffusion de documents scientifiques de niveau recherche, publiés ou non, émanant des établissements d'enseignement et de recherche français ou étrangers, des laboratoires publics ou privés. 
This article was downloaded by: [Bibliotheque Universitaire de Droit]

On: 14 October 2010

Access details: Access Details: [subscription number 917027137]

Publisher Routledge

Informa Ltd Registered in England and Wales Registered Number: 1072954 Registered office: Mortimer House, 3741 Mortimer Street, London W1T 3JH, UK

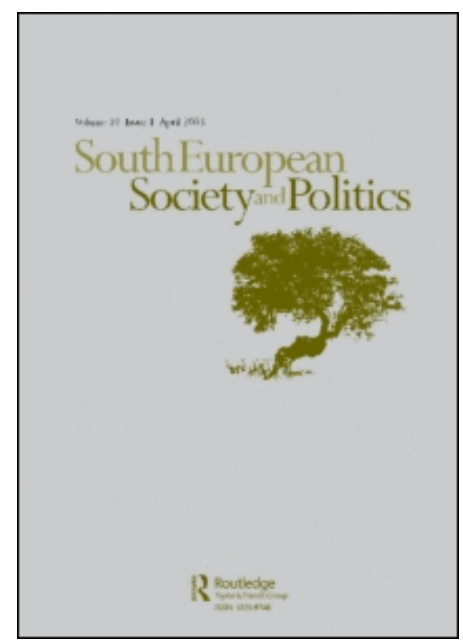

\section{South European Society and Politics}

Publication details, including instructions for authors and subscription information:

http://www.informaworld.com/smpp/title $\sim$ content=t713636479

\section{Italy: Still a Pro-European, but not a Fully Europeanised Elite?}

Christophe Roux; Luca Verzichelli

Online publication date: 26 July 2010

To cite this Article Roux, Christophe and Verzichelli, Luca(2010) 'Italy: Still a Pro-European, but not a Fully Europeanised Elite?', South European Society and Politics, 15: 1, 11 - 33

To link to this Article: DOI: 10.1080/13608746.2010.496920

URL: http://dx.doi.org/10.1080/13608746.2010.496920

\section{PLEASE SCROLL DOWN FOR ARTICLE}

Full terms and conditions of use: http://www.informaworld.com/terms-and-conditions-of-access.pdf

This article may be used for research, teaching and private study purposes. Any substantial or systematic reproduction, re-distribution, re-selling, loan or sub-licensing, systematic supply or distribution in any form to anyone is expressly forbidden.

The publisher does not give any warranty express or implied or make any representation that the contents will be complete or accurate or up to date. The accuracy of any instructions, formulae and drug doses should be independently verified with primary sources. The publisher shall not be liable for any loss, actions, claims, proceedings, demand or costs or damages whatsoever or howsoever caused arising directly or indirectly in connection with or arising out of the use of this material. 


\section{Italy: Still a Pro-European, but not a Fully Europeanised Elite?}

\section{Christophe Roux \& Luca Verzichelli}

The aim of this article is to analyse the attitudes of Italian political and economic elites towards European citizenship through the results of a survey conducted in 2007. We begin with a discussion of the changing patterns of pro-Europeanism among Italian elites, within the framework of the recent deep transformations of the domestic political system. In order to understand how these transformations have affected the elites' attitudes towards European citizenship, we investigate the analytical dimensions covered in this special issue: identity, representation and scope of governance. We reach the conclusion that the Italian elite are still characterised by a clear pro-European profile. However, some hints of change are evident: in comparison with politicians, economic elites are more certain about their degree of support. Moreover, a growing difference emerges within the political class, as centre-left MPs are more oriented towards full pro-Europeanism.

Keywords: Political/Economic Elites; Citizenship; EU; Italy; IntUne Survey

The impact of the European Union (EU) on the Italian political system has received growing attention during the last decade. Several authors have emphasised the role of the process of Europeanisation (Fabbrini 2003; Giuliani 2006; Fabbrini \& Piattoni 2008) and its impact in the domestic sphere (Cotta et al. 2005). More specifically, the study of the Europeanisation of Italy has been the subject of several works in the field of policy analysis. ${ }^{1}$ However, the analysis of Italian elites' attitudes towards the different aspects of European integration does not yet seem very developed. In the past, many scholars shared the view that between the mid-1970s and the end of the socalled 'First Republic' in the early 1990s, Italy was a clearly pro-European country whose ruling class expressed stable preferences on this issue (Walker 1976). At first blush, this could be interpreted as a logical consequence of the 'socialisation hypothesis' (Hooghe 2002), which proposes that longer duration of membership determines a more solid and coherent form of pro-Europeanism. However, the deep transformations in the Italian political system, following the crisis of the early 1990s, 
have paved the way to some degree of Euro-scepticism, not only in the marginal radical fringes of the political spectrum but also, to some extent, at its core.

In order to understand this shift, it is useful to recall some basic features of the Italian party system. After about 45 years of stability of the old 'polarised pluralism' grounded on a predominant party in government (Christian Democracy) and the strongest communist party of the Western world on the opposition side (Sartori 2005), the so-called 'Second Republic' has coincided with dramatic changes. On the one hand the dissolution of the largest parties determined the birth of a large number of small, uncertain political formations. On the other hand, political competition was disciplined by a clear trend towards bipolarisation: two opposing coalitions (usually referred as 'centre-left' and 'centre-right', in spite of the inclusion of radical components) competed and won alternatively each general election in 1996, 2001, 2006 and 2008. The alternation in power between left and right coalitions was a new feature in a country where the two political actors formerly positioned at the extreme poles, the Communist Party and the neo-fascists of the Italian Social Movement, had been never involved in government.

However, the growing role of the two main coalitions forced them to incorporate political subjects that were more radical than older parties (i.e. orthodox communists on the left and northern regionalists on the right). When the data used in this article were being collected, the political configuration was the one that resulted from the 2006 general election: a slight majority for a very broad and litigious centre-left electoral coalition called 'The Union', including all the political parties from the radical left to a good part of the centre, and a parliamentary opposition made up of the centre-right parties' 'House of Freedom' (Silvio Berlusconi's Forza Italia, the post-neo-fascist party of the National Alliance, Northern League and Christian Democratic Union of the Centre). ${ }^{2}$

Recent studies have shown that some components of the centre-right coalition-in government between 2001 and 2006 and again after the 2008 elections-seem increasingly exposed to the temptations of Euro-scepticism (Bellucci 2005; Conti 2006; Conti \& Verzichelli 2005). This phenomenon has been observed to an extent that varies according to the political and economic juncture and to the nature of the political and economic actors taken into consideration. However, clear changes have been observed only at the level of political elites (Bellucci 2005; Maniscalco 2006), while the orientations of other economic and social elites have been almost completely neglected thus far.

The aim of this article is to provide a more systematic assessment of the attitudes of Italian elites towards European integration, a crucial question in the broader research programme on European citizenship run by the IntUne project. The data we present here constitute the main findings of the first wave of the elite survey planned by the project. One hundred and twenty-eight interviews were performed in Italy from February to June 2007, 84 with members of political elites (MPs from the Camera dei deputati) and 42 with members of economic elites (top managers from leading Italian firms and interest associations). ${ }^{3}$ As a matter of fact, the two most important control variables that will be tested in this article are the nature of the elite 
(political vs. economic) and, for political elites, the effects of the belonging to the centre-left vs. the centre-right. ${ }^{4}$ However, the representative sample of the political elite can also be examined from the point of view of other variables, like the presence of women, expert professional politicians, frontbenchers, age, and others.

Members of the economic elites were managers from the following economic sectors: industry, banking, trade and services, public utilities, transport companiesto which we added leaders of top economic associations.

The hypothesis driving our work is that the ruling class in today's Italy is characterised by some significant variations in its views about European citizenship. This general assertion presupposes a double complexity. A first complexity relates to the composite nature of the elite, whose attitudes towards European integration and its consequences are multifaceted. This may be attributed to a number of possible explanatory factors, such as political culture, functional role, career strategy (pure domestic elites vs. prospective 'supranational leaders'), generational divide and different degrees of involvement in 'European life'. The second complexity concerns the multidimensional nature of pro-Europeanism: although somewhat correlated, the attitudes we are talking about are not necessarily consistent and their intensity can vary.

To address these complexities, we include a number of different variables in our analysis. First, we have to articulate the plausible patterns of pro-Europeanism of the Italian domestic elite by controlling the degrees of homogeneity of the attitudes concerning the three dimensions of the notion of citizenship (Benhabib 2002) identity, representation, and scope of governance-which were used in the research design of the IntUne project. Then, we have to explore the factors, derived from the research design used in the project, which can explain the different attitudinal patterns showed by Italian 'rulers'. Given the limited data available, after one only wave of interviews our attempt will remain mainly an exploration, rather than a full-fledged interpretation. Nevertheless, we aim to provide a more focused discussion of our working hypotheses, and to offer some significant implications to be used in a broader comparative perspective.

What do we mean when we talk about elites' pro-Europeanism? Following the framework of this special issue, we aim to address three main questions that seek to explain different views about identity, representative capability of domestic and supranational institutions, and prospective scope of EU governance. Our empirical questions can be summarised as follows. First, for the notion of identity, we want to clarify how Italian elites feel about belonging to a European entity. Second, for the level of representation, we raise the question of which institutional mechanisms of European representation are more welcome among the national ruling class. Finally, for the scope of EU governance, we need to understand whether, according to Italian domestic elites, the prevalence of a system of state-centred policies is still a viable option, or has to be reduced further. In other words, to what extent are these elites ready to accept institutional (or rather policy) changes in the current organisation of the relationships between EU, member states and decentralised bodies (regions, in the Italian case)? As a consequence, a descriptive analysis is first needed in order to assess 
to what extent the attitudes expressed by Italian elites in these three fields can be labelled 'pro-European'. In a second step, close attention should be paid to the way these attitudes are distributed. If we adopt the assumption of a consistent distribution of proEuropean and sceptical attitudes, we should expect orientations along these three analytical dimensions to be significantly homogeneous: a very high degree of identification with the supranational polity should thus correspond to a high degree of trust in EU institutions, as well as corresponding to a strong claim for a further extension of EU governance. But is this assumption valid? That is, do we empirically observe a consistent system of values and representations that structure Italians elites' perceptions about these dimensions of citizenship? We should not exclude the possibility that attitudes could be distributed more autonomously from one dimension to another, thus creating a complex and less coherent system of orientations.

In disentangling the complexities of our central notion, the analysis of the Italian case could represent an interesting exploration. Previous works on European support within the Italian political elites have often been grounded on the argument that the 'core elite' (the ruling class sensu stricto, i.e. representatives from governmental parties and the economic elite) is characterised by a 'full pro-Europeanism' in comparison with the 'peripheral' elites (in particular the leadership expressed by the extreme parties), which are, on the contrary, more sceptical. However, a detailed survey-based analysis of the different components of the pro-Europeanism of Italian elites has not been proposed so far.

As mentioned before, some authors have recently pointed out that, after a long cycle characterised by a progressively consensual pro-European alignment of the whole Italian ruling class, new elements of variation have started to emerge in recent times. These researches represent the basis for the starting assumptions of this article: for instance, the appearance of some uncertainties within the political elite about the meaning of European integration (Maniscalco 2006) would determine, in the perspective of our research, more room for some 'declaratory' Europeanism of politicians vis-à-vis other elite sectors. Another important argument to be verified here is the growing discontent with regard to the current shape of the EU within the centre-right political elite (Bellucci 2005, p. 220), which is emerging as a possible dividing issue between the dominant political actors. The analyses based on the evidence of previous researches have presented a possible - although rather weakchallenge to the traditional pro-Europeanism of governmental political elites and, therefore, the appearance of some forms of more critical pro-Europeanism. From this perspective, our data can provide another point in time to control these hypotheses.

The rest of this article is composed of three main sections. In the first section, we present our data about the attitudes of Italian elites towards European integration. In the second and the third section, we discuss the different components of elites' proEuropeanism in Italy by presenting the different facets of this attitude and by trying to interpret it. We sum up the main findings in the conclusion. 


\section{The Attitudes of Italian Elites towards European Integration}

\section{Between Local, National and European: The Identity of the Italian Elite}

In the classical configuration of the nation-state polity, national identity is expected to represent the prevailing frame of reference for individual members of a domestic elite. However, other lower and higher levels of polity identification can challenge this traditional value or simply add to it. At the lower level, conflicting identities sometimes oppose the national and sub-national levels, a tension that is confined to some areas, but which from a historical perspective (Rokkan \& Urwin 1983) is quite widespread across Europe. In Italy, for example, some regions like Val d'Aosta and Alto Adige have historically revealed a strong identitarian appeal, to which should be added the more recent successful mobilisation of the Northern League, especially in some northeastern areas. From above, the creation and development of a supranational political community such as the EU may weaken the strength of the feelings of national identity. Moreover, in the Italian case, national identity is said to be weaker than in other countries. The data provided by our survey on this point (Figure 1) illustrate a particularly interesting picture: all four levels elicit a strong sense of attachment but the economic elite shows a rather weaker attachment to the regional level and, to a lesser extent, to the European level. On the whole, a clear pattern of multi-layered identity is shown by Italian elites.

The structure of such a multi-layered pattern is quite remarkable. Italian elites express a strong attachment to their country (100 per cent of economic elites and 94.1 per cent of political elites are very or somewhat attached) as well as to their town/village ( 91.8 per cent of political elites, 88.4 per cent of economic elites). This means that national and local polities are the first sources of identification. It is perhaps surprising that regional identities are not able to score as high as the former levels. Regions represent a level of governance that has taken on a growing importance through the territorial reforms launched in the 1990s and known today as 'federalisation' (Baldi \& Baldini 2008); moreover, even the parties that were rather reluctant to accept such a trend have joined the federalist side in the period of the Second Republic (Mazzoleni 2009). However, one should not overlook the fact that regions are not that 'natural' in Italy. One reason is that their borders do not always define a clear territorial identity (consider, for instance, Umbria or Marche). Another is that regions are latecomers among the infra-national subdivisions; they were institutionalised during the Republican era, while communes and provinces, following the French model of territorial organisation, have been present since the beginning of national unity. Furthermore, before Italy's unification, traditional divisions were often organised around cities, which, when engaged in rivalry, had the power to weaken regional identification. All these reasons are likely to help explain the relatively low performance of regions. Why, though, do political elites still express a stronger regional identification than economic elites? This difference probably has to do with the fact that while MPs see regional identity as a source of legitimacy (how could an elected politician declare that they do not like the region where they live, especially when that region is also their constituency of election?), economic elites are usually operating in broader territorial environments. 


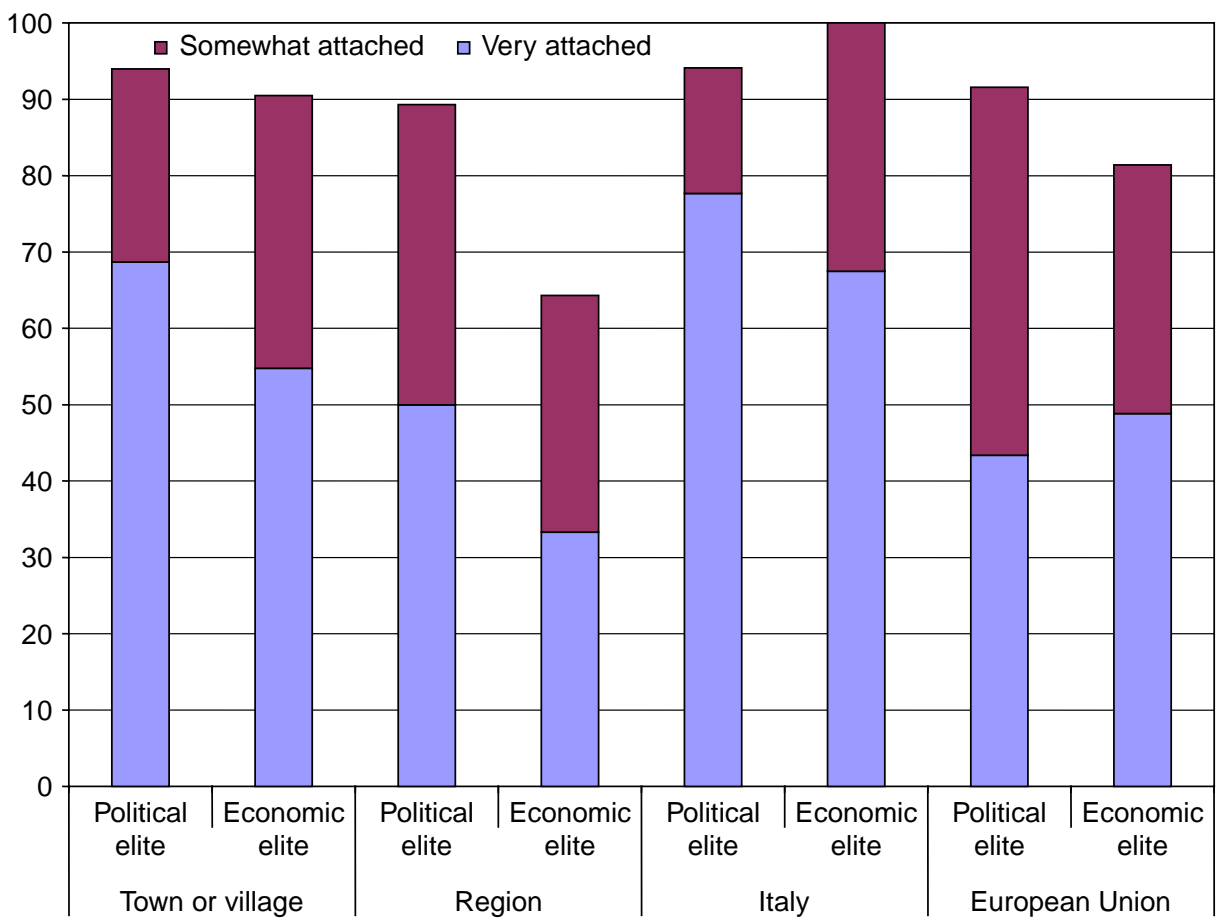

Figure 1 Attachment of Italian elite to their own town/village, region, Italy, EU (per cent of respondents).

Source: IntUne 2007 Elite Survey in Italy

As a source of identity, the EU is clearly weaker than national identity but at least it reaches the same levels of identification received by regions: 89.5 per cent for political elites, 81.4 per cent for economic elites. However, as for regions, the intensity of this feeling of attachment is significantly lower than it is for national and local identity: those who declare themselves to be 'very attached' to the EU represent 44.5 per cent of the sample, while those very attached to Italy are 74.2 per cent. Despite the two-fold process of deepening and widening of the EU, which tends to make nation-states less central than in the past, the Italian nation still elicits a clear identification among interviewed elites, with few exceptions (due to the presence in the sample of members of the Northern League or other regionalist political forces). However, the EU has quite a strong capacity for generating identification among members of the elite, with no major differences among the sub-groups analysed here.

Hence, these data confirm that, for the Italian elites, national identity is far from being as weak as is commonly believed. Campanilismo (local community feeling) and Europeismo are less relevant than national identity, and they tend to go together with it; at the same time, they show that, thus far, regions are not really able to challenge national identity. 


\section{Defining National and European Identity}

While the above mentioned data indicate the territorial levels to which Italian elites are attached, we still have to understand whether there are qualitative differences in their conception of identity. In order to control this element, two batteries of questions were asked about the criteria that should be used to best define Italian and European identity (Table 1).

Most of the criteria proposed in the survey seem to be important in defining the components of Italian and European identities. There are no huge differences in the relative importance given to each criterion in defining the national rather than the European identity. Hence it seems that, for the Italian elites, the notions of national and European identity are built roughly in the same way. However, some differences emerge when we consider the two most divisive dimensions: religion and family origins. In both samples, respondents are more or less equally divided over the element of Christianity, thus reflecting the polarisation on religion which exists in Italy. On the other hand, family origin as a criterion for defining identity seems to be less relevant for the economic sector of the elite, and this difference is particularly evident with regard to supranational identity.

If we limit our analysis to respondents who consider the items in the two batteries of questions to be 'very' important, some other variations emerge; on the whole, the economic elite seems more 'prudent' in considering these items to be crucial components of national and European identity.

\section{Threats to EU Cohesion}

We can now refer to the battery of items from the IntUne questionnaire concerning the threats to EU cohesion, in order to understand the variations in the elites' perceptions about the consolidation of a supranational order. The data show that there is a general consensus on stressing the rise of nationalist attitudes in some member states as the main threat to the future of EU. The economic and social differences between member states are also understood to be an important threat: this is what 59 per cent of the political elite and 53 per cent of the economic elite think. The other phenomena are not perceived as strong menaces. However, some important differences according to the type of elites and, among MPs, according to political orientation can be discovered. MPs from the centre-right perceive issues such as enlargement (with special emphasis on Turkey) or immigration from outside the EU to be serious threats, while the centre-left is more worried by American or Russian interference, by the effects of globalisation and, above all, by the emergence of nationalist attitudes.

In the comparison between political and economic elites, the issue of whether enlargement of the EU should include Turkey or other countries generates more concern among economic elites $(+21.8$ for Turkey and +22.2 per cent for other countries compared with MPs) while globalisation is seen much more positively (-29.4 per cent). 


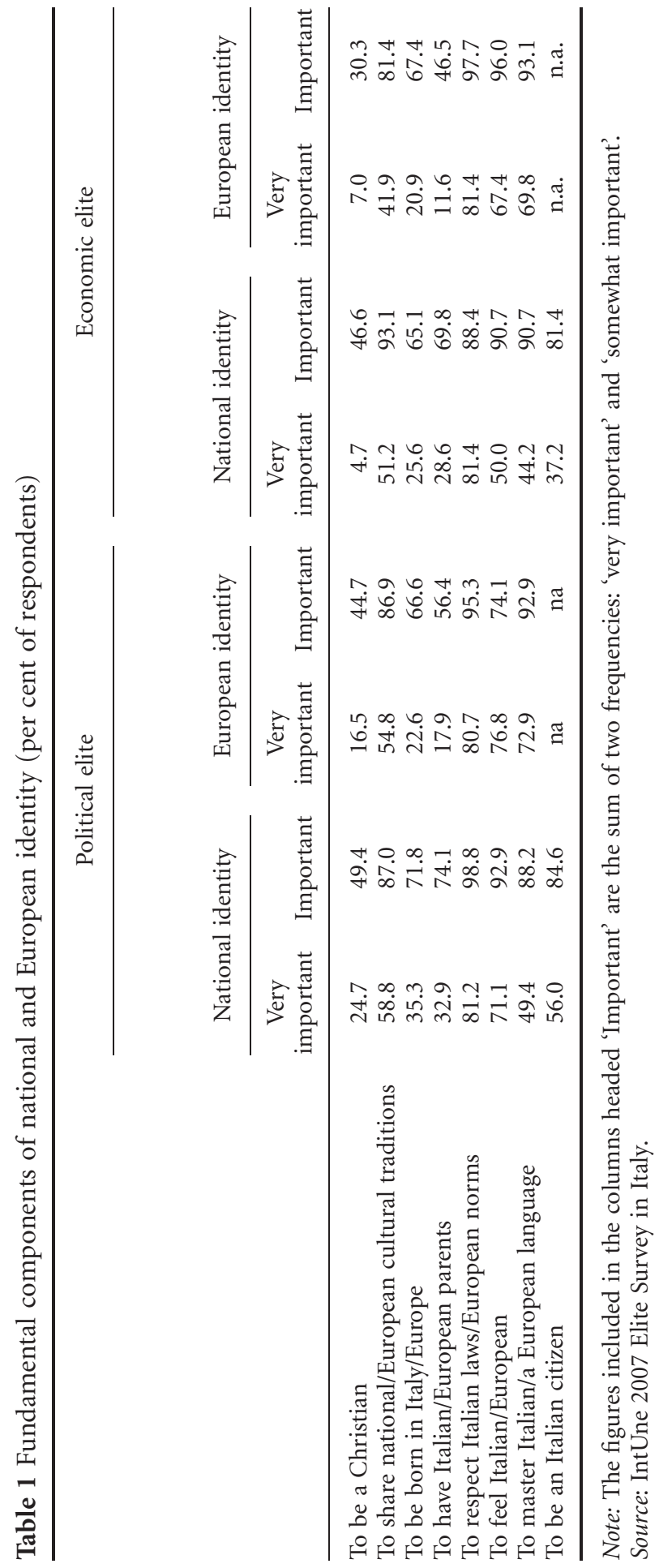




\section{The Nature of the EU and the Transformation of Political Representation}

The second dimension of the IntUne research design concerns visions of EU institutional settings and political representation. On the whole, the Italian elites' judgement of the EU is highly positive: 94 per cent of politicians (100 per cent within the centre-left cohort) and 93 per cent of the economic elite say that Italy has benefited from its EU membership. This result confirms the high level of pro-Europeanism usually observed in Italy. Coming to more specific issues about future EU development (Table 2), political and economic elites reveal very similar opinions on the main proposals: they are both favourable to an increase in the power of the European Commission and of the European Parliament (EP), but at the same time they would both prefer to maintain the role of member states as the main actors of the EU (54.1 per cent of MPs, 65.1 per cent of economic actors). This paradox is particularly marked among centre-right MPs and, to a lesser extent, within the economic elite, but it can be put into perspective by looking at the 'strongly agree' answers: for instance, within the considerable majority of centre-right MPs who agree with an increase of the power of Commission and EP, no more than one-third say that they 'strongly agree' with this statement.

All in all, the Italian elite tends to demonstrate a massive pro-Europeanism, which can be characterised as somewhat 'declamatory'; affirmations in favour of an 'ever closer integration' are not followed, in fact, by full support for the stronger capability of EU institutions. ${ }^{5}$ However, the perceptions about benefits of and positive perspectives of European integration are much more marked than a narrow defence of national interests, thus confirming the traditional acquiescence of Italian decisionmakers vis-à-vis the supranational system (Cotta et al. 2005).

\section{Trust in Institutions}

The structural dissatisfaction concerning the way democratic institutions work in Italy has been extensively studied at the mass level (Morlino \& Tarchi 1996). In such a context, Italians tend to consider themselves 'rescued by Europe' (Ferrera \& Gualmini 2004), since the EU has worked as an external pressure towards improving the functioning of a number of mechanisms of the domestic political system (Dyson \& Featherstone 1996). Do the Italian elites share a similar perception? Here again interviewed elites were asked to indicate on a $0-10$ scale their degree of trust in a series of institutions. The comparison between political elites and economic elites is not fully symmetric, since the latter were asked to evaluate their trust both in domestic and in EU institutions, while MPs were only asked (in order to avoid biased answers) to indicate their position with regard to European institutions.

The economic elite are clearly more oriented to trust European institutions than the national ones: the average values in the scale are 5.8 for the European Commission, 5.5 for the European Council of Minister and 5.4 for the EP, while the national parliament receives a grade of 5.0 and both national and regional governments are below 5 . The abovementioned gap is therefore confirmed, although the disparity does 
20 C. Roux \& L. Verzichelli

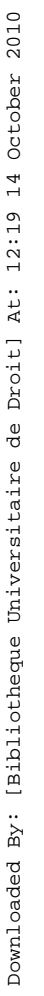

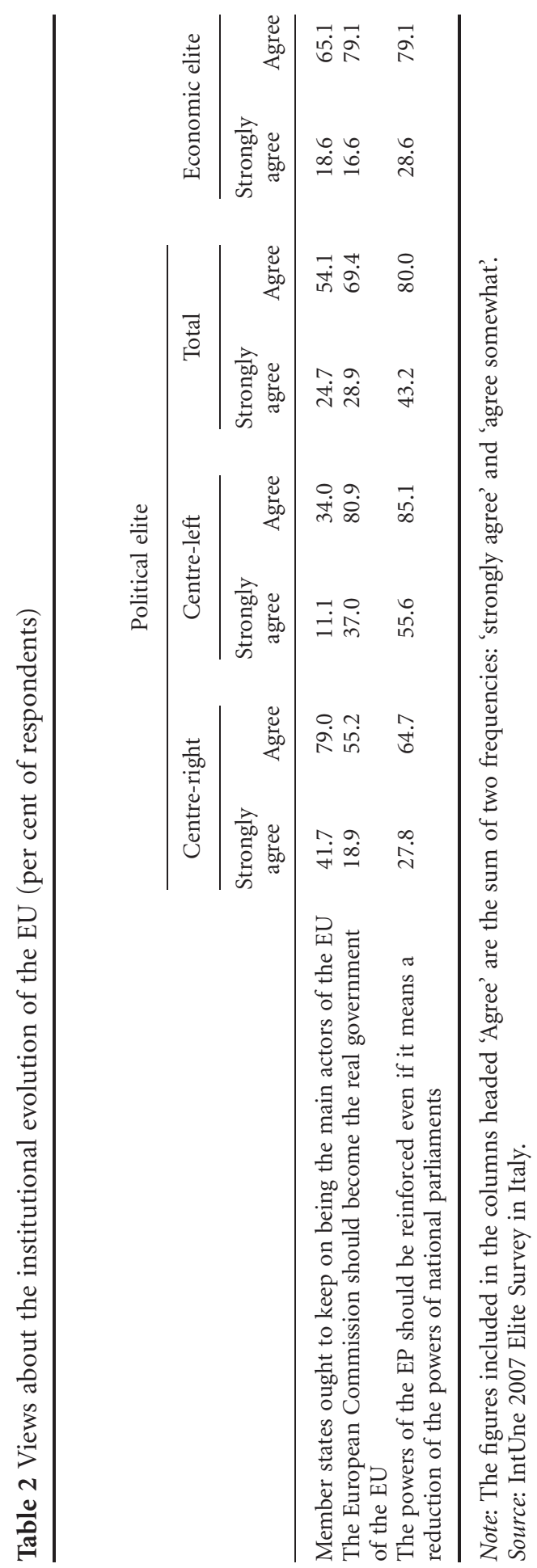


not seem too wide. When we look at the orientations of politicians, a clear gap between centre-left and centre-right politicians emerges. MPs supporting the centre-left Prodi II cabinet (in office when the survey was conducted) express a high level of trust in the Commission (6.6) and the EP (5.9) but they are less trustful of the Council of Ministers (5.4). In contrast, MPs from centre-right show a reversed set of preferences, being less enthusiastic about the European Commission (5.0) and more trustful of the Council (5.6). The centre-right profile of preferences on the institutional scenario resembles a sort of intergovernmental configuration. Overall, while political elites express contrasting views that can be linked to their political affiliation, economic elites express a global mistrust in national institutions (a feeling that is part of Italian political culture) and a limited trust in European institutions.

\section{Attitudes towards EU Governance}

With regard to the EU scenario unfolding over the next ten years, a few questions included in the questionnaire concerned preferences for further integration and the strengthening of some key sectors of EU intervention (taxation, foreign, social and regional policies). All of these developments received a massive approval, from 76.3 to 93.6 per cent (Table 3). One may note that the approval by centre-right MPs is structurally lower than that expressed by their centre-left colleagues, with the relevant exception of the item about a common social security system, where centre-left MPs look more cautious. Since it is rather difficult to understand the meaning of the different attitudes in terms of true policy orientations, we should limit our speculations, pointing out that, overall, the support for an effective empowerment of the EU in these fields prevails. The only item that seems to be more problematic here is the issue of a unified tax system. However, even that is supported by a majority of respondents (more than 60 per cent of MPs and more than 70 per cent of economic actors).

Table 4, reporting the distribution of preferred levels of governance in a number of policy domains, better clarifies the preferences within our elite sample concerning the future scope of governance of the EU. Overall, the profiles of the political and economic sectors of our elite sample are not so dissimilar, since they share the view that

Table 3 Support for prospective evolutions of the EU over the next ten years (per cent of respondents very or quite in favour)

\begin{tabular}{lcccc}
\hline & \multicolumn{3}{c}{ Political elite } & \\
\cline { 2 - 4 } & Centre-right & Centre-left & Total & Economic elites \\
\hline Unified tax system & 50.0 & 70.2 & 61.2 & 72.1 \\
Common system of social security & 93.6 & 84.2 & 89.4 & 79.1 \\
A unique European foreign policy & 78.9 & 97.9 & 89.4 & 90.7 \\
More assistance for regions that suffer & 76.3 & 91.5 & 84.7 & 79.1 \\
from economic or social difficulties & & & & \\
\hline
\end{tabular}

Source: IntUne 2007 Elite Survey in Italy. 


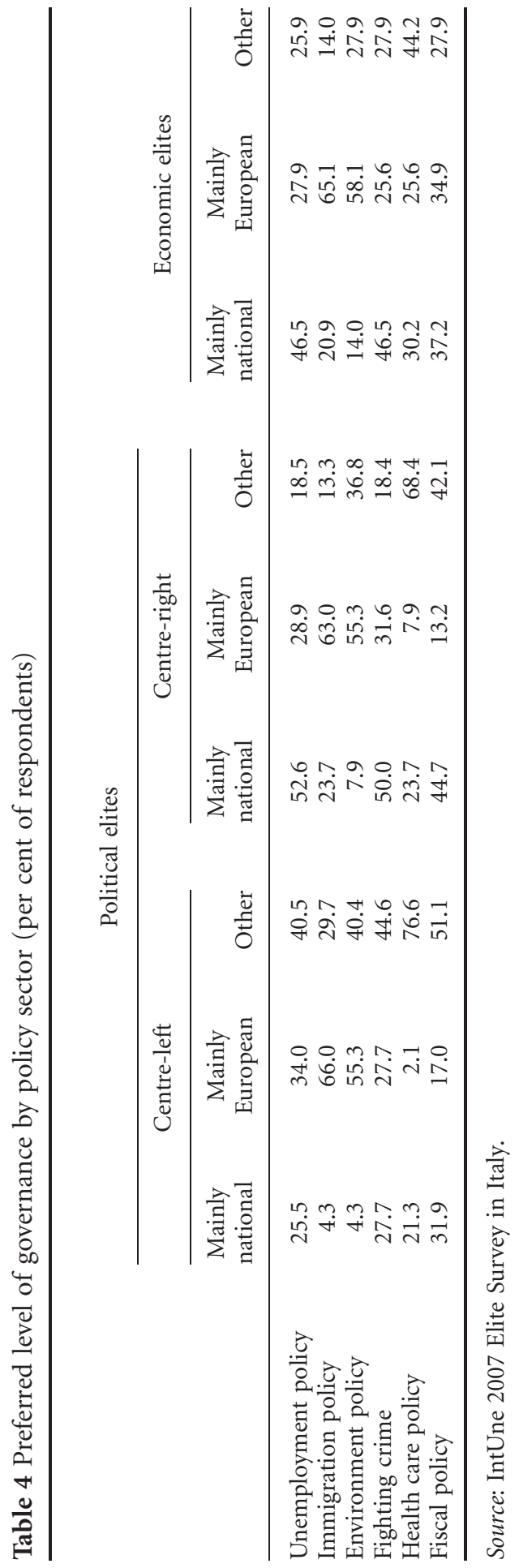


immigration and environment issues should be dealt with at the supranational level, while other issues, such as health care or unemployment, should be managed mainly at the national level. However, a structural diversity — namely a more pro-European vision in the centre-left-emerges in policy sectors like unemployment and crime when one considers the political positions of MPs. A similar pattern, but with much less distance between the two groups, emerges in the domains of immigration and fiscal policy, while the sectors of environment and health care do not show significant differences. Interestingly, the economic elite seems to have much more marked preferences, leaning toward centre-left 'Europeanism' in some areas (i.e. immigration and environment) but also showing a strong preference for the national level in the future management of other areas (particularly, unemployment and crime).

\section{Defining the Faces of the Italian Elite's Pro-Europeanism}

It's time to summarise the data discussed so far and to search for a first interpretation of the multidimensional orientations of the Italian elite, concerning present and future EU development. Are there dominant patterns of orientations towards European integration, and if so, what are they? Correlation and factor analysis can be adequate instruments to detect the relationships among a selected number of indicators, covering the different dimensions analysed above.

To start with, we present some significant correlation coefficients, first among the indicators of attachment and then between these indicators and the answers on the perceived threats to the EU. We can immediately notice that attachment to the EU (measured on a four-point scale) is correlated with attachment to the national polity (0.307), while attachment to the region is particularly correlated with attachment to town/village (0.448). This means that MPs and top economic leaders in Italy tend to see themselves as European and Italian (or Italian and European) in a complementary manner. Within the battery of items concerning 'threats to the EU', the perception of the enlargement to include Turkey as a relevant threat is negatively correlated with EU attachment $(-0.335)$, while the fear of nationalist attitudes within the member states is associated with EU attachment (0.385). Another measurement of support for integration-the position on the $0-10$ scale from 'unification has gone too far' to 'unification should be strengthened' — confirms a good deal of consistency among our indicators. However, this variable is more correlated (negatively) with the perception of enlargement to include Turkey as a threat -0-.486) and with the vision of the European Commission as a 'government' (0.323), than with the expression of attachment to the EU (0.259).

Coming to the representative role of EU institutions, the measurements provided by the three questions dealing with trust (in the EP, the Commission and the Council) look quite consistent (Cronbach's alpha $=0.861$ ). This allows us to build a unique scale of EU institutional trust, which is weakly correlated both with attachment to the $\mathrm{EU}(0.299)$ and to the scale from 'integration has gone too far' to 'integration should be strengthened' (0.238). Unsurprisingly, there is a stronger negative correlation 


\section{Roux \& L. Verzichelli}

between the reactions to two general questions about the European governance: 'the power of the EP ought be strengthened' and 'member states ought to remain the central actors in the EU' (0.312). However, the analysis of correlations does not present consistent evidence of a unidimensional pro-European distribution: indeed, our scale of EU institutional trust is more correlated with attachment to Italy (0.303) than with any other proposition in favour of an increase of the EU's scope of governance.

A factor analysis can be performed, in order to distinguish the latent dimensions of variation in this complex game. Table 5 reports the result of an analysis conducted on 11 variables, which extracts three latent factors explaining about 60 per cent of the variance. Several variables are closely linked to a first factor: the indication of enlargement to include Turkey as a possible threat to EU cohesion (negative), attachment to Europe, assessment on further unification, trust in EU institutions and assessment on EU decisions that do not take account of national interests (of Italy). As one can see, all these variables have to do with the identity dimension of the European citizenship: economic and political elites look quite coherent in taking a position about a series of elements of EU identity.

Table 5 Factor analysis: dimensions of pro-Europeanism of Italian domestic elite (factor loadings)

\begin{tabular}{|c|c|c|c|}
\hline \multirow[b]{2}{*}{$\begin{array}{l}\text { Enlargement to Turkey is a threat (1: strongly disagree; } 4 \text { : } \\
\text { strongly agree) }\end{array}$} & \multicolumn{3}{|c|}{ Factor loadings } \\
\hline & -.681 & -.114 & .174 \\
\hline Attachment to Europe (1: not attached at all; $4:$ very attached) & .646 & -.197 & .293 \\
\hline $\begin{array}{l}\text { Assessment on unification (0: unification gone too far; } 10 \text { : } \\
\text { unification should be strengthened) }\end{array}$ & .707 & .093 & .057 \\
\hline Trust in EU institutions (scale 1-10) & .733 & .231 & 373 \\
\hline $\begin{array}{l}\text { Those who make decisions at the EU level do not take enough } \\
\text { account of the interests of Italy (1: strongly disagree; } 4 \text { : } \\
\text { strongly agree) }\end{array}$ & -.661 & .123 & .079 \\
\hline $\begin{array}{l}\text { Growth of nationalist attitudes in European member states is a } \\
\text { threat (1: strongly disagree; } 4 \text { : strongly agree) }\end{array}$ & .416 & .668 & .091 \\
\hline $\begin{array}{l}\text { On being truly European: how important do you think it is to } \\
\text { feel European? (1: strongly disagree; } 4 \text { : strongly agree) }\end{array}$ & -.281 & .801 & .033 \\
\hline $\begin{array}{l}\text { On being truly European: how important do you think it is to } \\
\text { master a European language (1: strongly disagree; } 4 \text { : } \\
\text { strongly agree) }\end{array}$ & -.215 & .667 & .370 \\
\hline $\begin{array}{l}\text { Economic and social differences among member states are a } \\
\text { threat to the EU (1: strongly disagree; } 4 \text { : strongly agree) }\end{array}$ & .080 & .156 & .778 \\
\hline $\begin{array}{l}\text { Approve or disapprove of a unified tax system for Europe in } \\
\text { ten years }\end{array}$ & -.421 & -.413 & .504 \\
\hline $\begin{array}{l}\text { Out of } € 100 \text { of tax money a citizen pays, how much should be } \\
\text { allocated to EU level? }\end{array}$ & .036 & .468 & .553 \\
\hline$\%$ total variance explained (cumulative) & 29.2 & 46.5 & 59.2 \\
\hline
\end{tabular}

Note: Extraction method: principal axis factoring. Rotation method: Oblimin with Kaiser normalisation.

Source: IntUne 2007 Elite Survey in Italy. 
The second factor emerging from the analysis indicates another dimension of proEuropeanism which can be defined as the willingness to remove the obstacles to the creation of a European multi-level identity: here, the basic variables included are the fear of nationalism in Europe, the necessity of stronger European feeling and the necessity of mastering (at least) one other European language in order to become truly European. Finally, three variables define a third component which can be defined as the 'concreteness of pro-Europeanism': here, economic and political elites seem to be relatively coherent in expressing clear orientations about the future of EU governance (in particular, the approval of a unified tax system in ten years and the opinion according to which economic and social differences are an important threat and that a relatively high reallocation of tax money at the EU level should be reallocated).

The analysis confirms that Italian elite pro-Europeanism is a complex multidimensional phenomenon. Apparently, all the variables grouped by the first component relate to some identitarian elements of pro-Europeanism, while the other two dimensions refer to the concrete steps still to be taken in order to reduce nationalism and to strengthen European feelings and EU governance. Particularly, the second component has to do with openness to a sense of multi-level identity which is probably not necessarily connected only with appreciation of the process of European integration, but also with a sort of 'absolute supra-nationalism' which is per se felt as a value. The third group of variables is, on the contrary, clearly connected issues related to EU governance.

We can therefore argue that a more specific 'institutional Europeanism'-probably the most diffuse elite orientation-could be at odds with some other diffuse messages of cosmopolitanism or openness to the outside. At the same time, the orientations towards a more effective and wider EU scope of governance seem to be less diffuse but concentrated in the same groups of domestic economic managers and domestic politicians.

\section{Interpretative Analysis: Explaining a Multifaceted Elite's Pro-Europeanism}

According to what we have illustrated so far, we can conceive the Italian elite's proEuropeanism to be the result of a number of orientations contemplating different dimensions of supranational citizenship. Being attached to the EU as a polity can be paired with another sense of attachment (that to the national polity), but not necessarily with the idea of the enforcement of EU institutions or EU policies. On the one hand, it is true that we can exclude the presence of very significant sectors of the elite from completely disharmonic visions of European integration: virtually no respondent, within the elite sample covered in our survey, presents contradictory attitudes between one indicator and another. However, the preferences on the different dimensions do not exactly overlap: declamatory affirmations of EU attachment seem to be more widely shared than an enthusiastic trust in EU institutions and, even more evidently, the preferences about specific changes in the direction of a broader scope of EU governance do not necessarily overlap with the abovementioned enthusiasm for a 
strengthened representative role of the central EU institutions. Of course, such a descriptive framework cannot tell us very much about the factors impacting on this differentiated set of orientations. At this stage, with just one wave of interviews completed and a limited number of cases, we are not able to present a comprehensive multivariate analysis comparing the explanatory potential of some alternative independent variables. However, we can attempt a first interpretation by looking at the breakdown of the mean values of three measurements of the above indicated dimensions (Figure 2): the centre-left MPs are confirmed to be more Europhile in all the variables observed, although the relative distance between centre-left and centre-right seems to be much higher in the case of 'attachment' to EU and in that of the preference for stronger unification. Interestingly enough, the mean value for the economic elite always approaches the mid-point between centre-left and centre-right politicians.

On the basis of some of the already mentioned variables we can build a rough scale of pro-Europeanism within the Italian elite. ${ }^{6}$ The distribution of this index in the three elite sub-groups (Figure 3) is fairly consistent with our expectations: among politicians, centre-left MPs (supporting the government at the time of the survey) are more open to a high pro-Europeanism, while a significant portion of centre-right (opposition) MPs denotes a rather weak pro-Europeanism. However, both distributions are 'normal': the mid-category is the largest, since politicians tend to mix some general positive

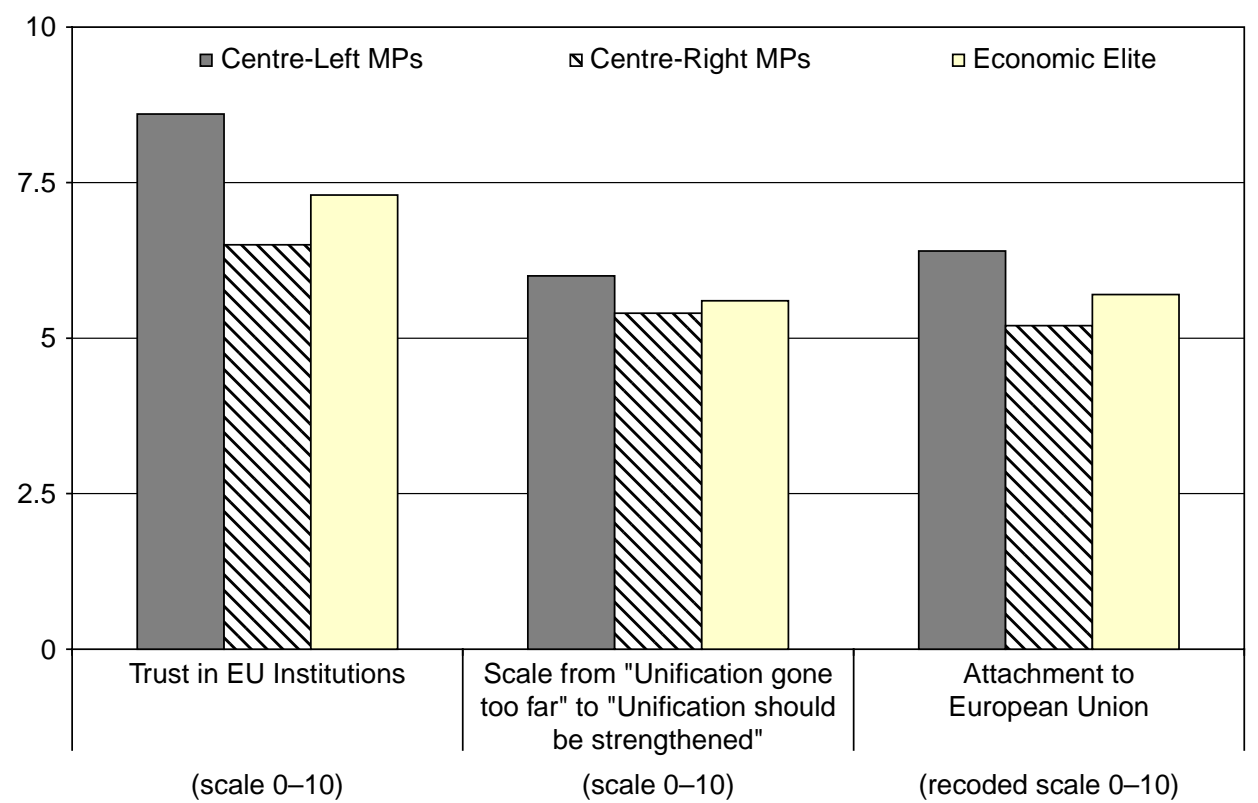

Figure 2 Mean values on three scales covering different dimensions of Pro-Europeanism. Source: IntUne 2007 Elite Survey in Italy.

Note: The three questions analysed here use a 0 (lowest level of trust in institutions, of support for strengthening European unification, of attachment to the EU) to 10 (highest level of trust/support/attachment) scale. 


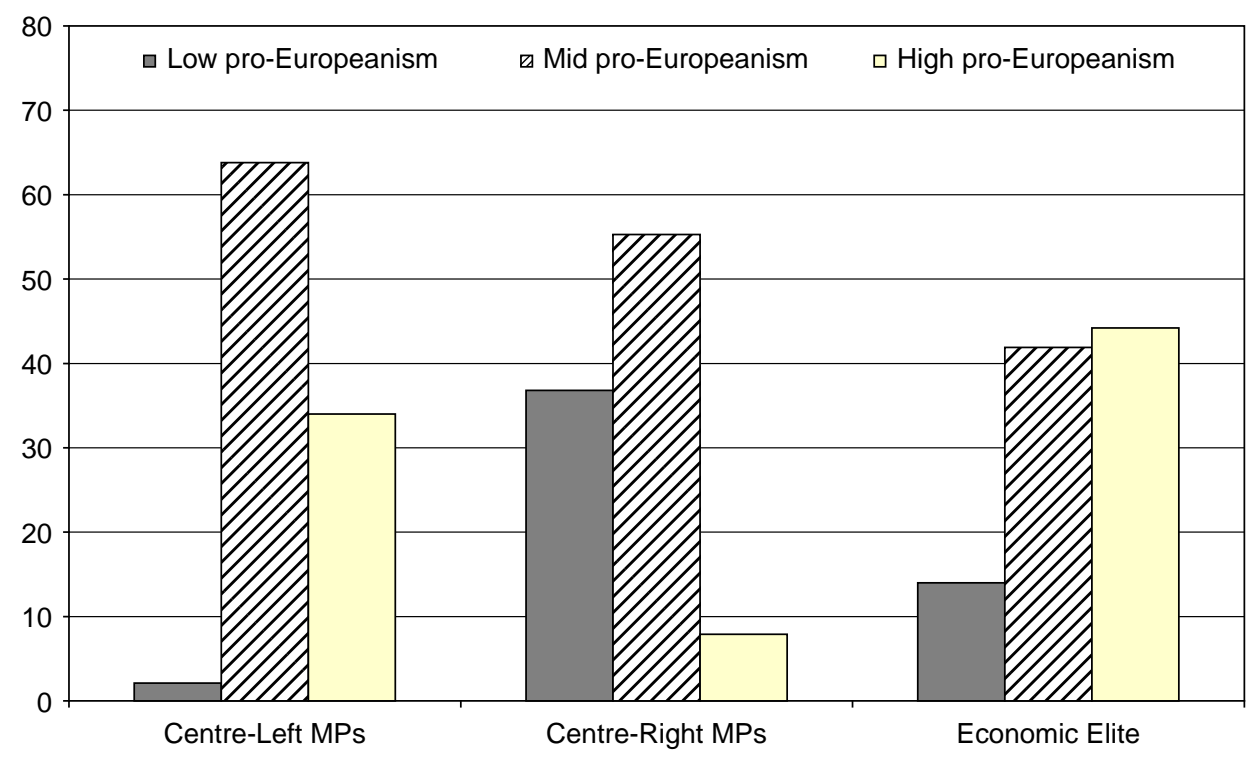

Figure 3 Distribution of an index of pro-Europeanism among three elite sub-groups. Source: IntUne 2007 Elite Survey in Italy.

Note: See note 6 for details concerning the construction of the three-point index of pro-Europeanism.

orientations towards Europe concerning different aspects of representation and scope of governance with some less favourable ones. Conversely, the distribution within the economic elite is more dispersed: apparently managers and interest representatives do not need to soften their positions on Europe and, in any case, their negative or positive answers on the different dimensions seem to be more coherent all along the way.

Is it possible to determine the factors explaining such distributions? The frequencies of our pro-Europeanism index can be cross-tabulated with a set of independent variables concerning the types of individuals, their position in the political continuum and even their answers to questions included in our survey which tap the supranational experiences of domestic elites and the reality of their 'Europeanisation'. The most relevant results from this explorative work-limited to the political eliteare reported in Table 6: once again, the centre-right/centre-left divide emerges, since the largest part of the MPs with a 'low pro-Europeanism' fall in the centre-right camp, while most of those with a 'high pro-Europeanism' are in the centre-left camp. However, the cross-tabulation shows the relevance of other variables that should be taken into account in more sophisticated analyses. First of all, if we exclude the Northern League from the centre-right camp and-above all-the two communist parties from the centre-left camp, the traces of a broad and harmonised Europeanism become much more evident. Those parties, although included in the two broad coalitions (the Northern League is still part of the centre-right camp), were in fact at 


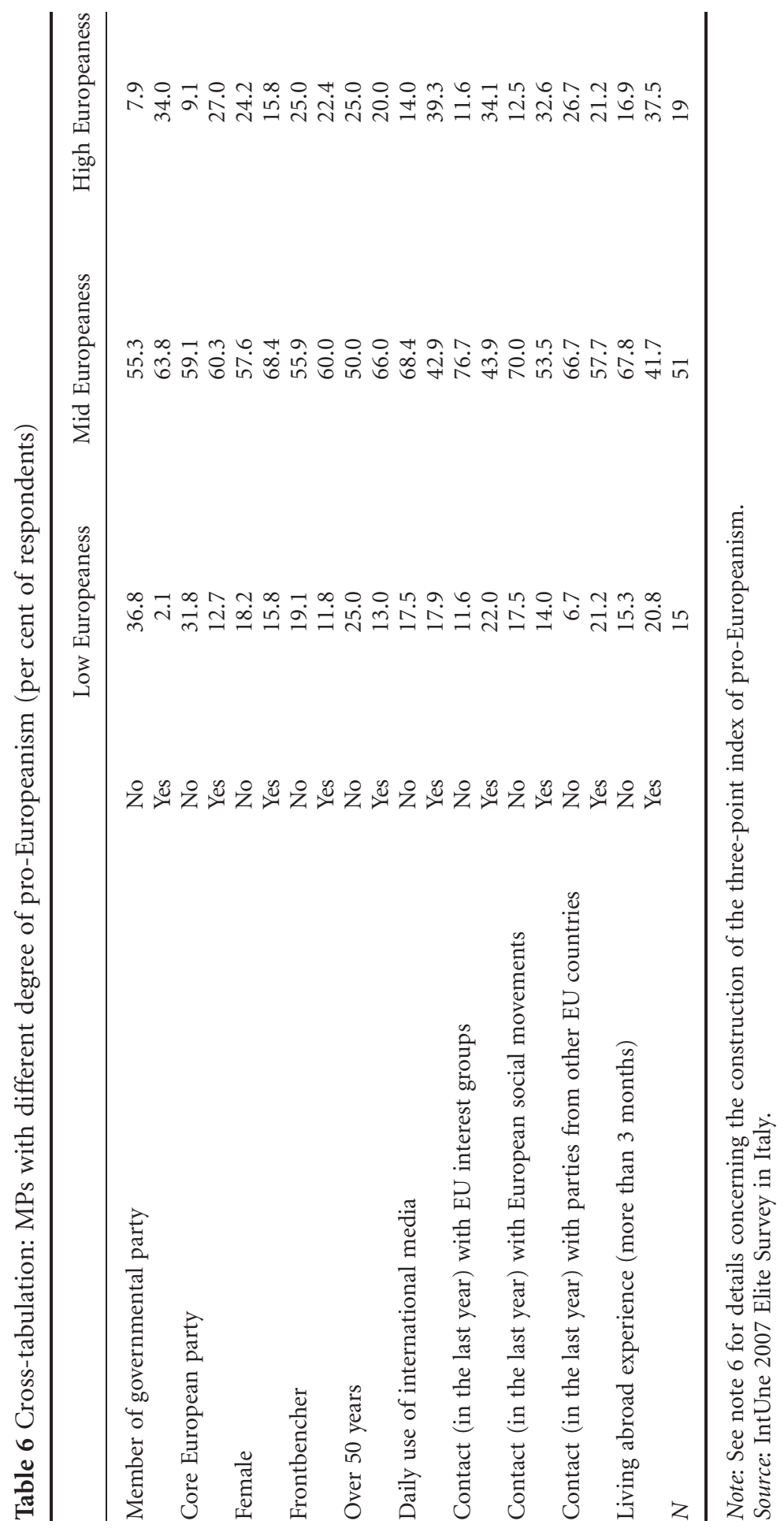


the fringe of them and tended to express very sceptical positions about Italian policies concerning both European and international issues. Hence, the role of the 'core EU parties' (parties belonging to EU big 'federations' vs. parties with no strong EU links), or the divide between 'moderate politicians' and extremists, seems to matter-thus confirming a common interpretation about the Europeanisation of parties (Szcerbiack \& Taggart 2007). According to this argument, more than the left-right continuum or the government-opposition status, the presence of parties in core vs. peripheral party families is a good explanation of pro-European elite orientations.

Moreover, other rows in the table indicate that some features which have to do with the degree of 'Europeanisation' of domestic politicians can be rather important in determining their orientations towards EU development. In particular if we compare-and these are issues that have been subject to further investigation (Best et al. 2010) — the apparent lack of impact of some structural variables (presence of women, frontbenchers, MPs over 50) with the following ones expressed in the last lines of this table, we discover that the use of international media, the frequency of contacts with European social groups and organisations and the experience of living abroad can be significantly relevant in increasing the pro-Europeanism of the respondents. On the contrary, the only variable in this list which seems to have no impact on this index is the frequency of contacts with parties from other EU countries, that is to say, the only indicator dealing with the consequences, more than the conditions, of a process of Europeanisation of the ruling class.

\section{Conclusion: Pro-Europeans but Not Always Europeanised?}

The general picture that emerges from this study substantially confirms the traditional broadly pro-European attitude of Italian elites. The hypotheses based on the argument of the rise of patently sceptical positions, originating between Maastricht and Amsterdam from the need for Italy to 'pay for Europe' (Sbragia 2000) are rejected by our data. The proEuropean orientation of Italian elites has not been seriously questioned by the political transformations of the last 15 years. However, the differences between the attitudes of centre-left and centre-right politicians (with the top economic actors positioned more or less between the two) constitute a consolidated pattern today, confirming the hints provided by previous research (Conti \& Verzichelli 2005; Bellucci 2005).

Our interpretation of this picture is the following: instead of a clear 'divide' between right and left politicians, we can simply talk about some differences in the degree of pro-Europeanism. It is partly emphasised by the presence of a clearly Euro-sceptical party within the centre-right camp-the Northern League, which adopts today the most sceptical profile even in comparison with the non-core parties of the left, such as the post-communist parties - and by the lower degree of socialisation within the EU party families of the politicians of National Alliance and even Forza Italia. (Long-term) membership within a mainstream European party family could be thus a good explanatory factor for elite attitudes-more than ideology or specific preferences about the future of Europe. 
Although at this stage we do not have sufficiently robust evidence to make a more detailed interpretation, we can argue that differences within the political elite are due to the presence of a more critical pro-Europeanism among centre-right MPs, which seems to be confirmed by their less enthusiastic support for a further deepening of EU governance. Conversely, centre-left politicians from core parties are more oriented towards a sincere pro-Europeanism. Nevertheless, the most striking evidence in our data is that the political elite is on the whole oriented towards milder expressions of pro-Europeanism, while the economic elites tend to express their attitudes towards Europe more strongly, showing the same degree of support for all the dimensions.

This last distinction between political and economic elites seems to create room for a more nuanced interpretation of elites' attitudes towards European integration, beyond the simple dichotomy 'in favour or against'. In particular, the more evident temptation among politicians to choose declamatory pro-European assertions, and the more attentive cognition about pros and cons of European integration among top manager vis-à-vis domestic politicians are interesting food for thought. At the moment, we can argue that, though globally confirmed, the elites' pro-Europeanism is structured in a rather complex way. It is true that we did not find strong signs of a disharmonic pro-Europeanism-that is to say, complete disconnection between effective knowledge of and interest in EU-related issues and the attitudes of different elite sectors. However, the overlap between the support for different dimensions of European citizenship is limited, and some elite sectors seem to express rather contradictory attitudes concerning the different components of their proEuropeanism: for instance, they can be substantially in favour of the need to complete the process of integration, and express at the same time a number of doubts about the shift of sovereignty to be made in a number of specific policy domains. This means that an attitude of coherent pro-Europeanism-that is to say a strong positive orientation in all the dimensions covered in our study-is not so widely shared.

If fully coherent and fully incoherent forms of pro-Europeanism are not so common, what are the most widely shared positions of the Italian elites? First of all, we can detect a diffuse practice of declaratory pro-Europeanism, which seems recurrent among members of the domestic elite-mainly politicians - whose positive visions of Europe seem to be a reaction/adaptation to a general or prevailing habit. In this case, the domestic elite indicates quite a pronounced attitude in favour of an 'ever closer integration', which is not necessarily balanced by a responsible vision of the costs of integration and by a strong emphasis on the representative capability of EU institutions. The domestic elite proves to be still very 'domestic' and relatively disinterested in the specific dimensions of supranational citizenship, despite its positive overall orientation towards European integration.

Secondly, we can also notice the diffusion of some forms of critical pro-Europeanism. This consists of a deeper reflection on the costs of (and threats to) European integration, and brings decision-makers to push for slowing down the whole process without changing their general positive judgement on the overall building of a common identity. In contrast with the previous type of Europeanism, the elite 
discourse is here somewhat critical of a further deepening in some specific aspects of EU policymaking.

\section{Acknowledgements}

This research was funded by a grant from the IntUne project (Integrated and United: A Quest for Citizenship in an Ever Closer Europe) financed by the Sixth Framework Programme of the EU, Priority 7, Citizens and Governance in a Knowledge Based Society (CIT3-CT-2005-513421).

\section{Notes}

[1] The literature is rather dense in this field (Ferrera \& Gualmini 2004; Radaelli \& Franchino 2003; Gualini 2004; Graziano 2004; Brunazzo 2005; Bolgherini 2006; Fargion et al. 2006).

[2] Later on, the main parties of each coalition merged, in order to create the Democratic Party (formed by the main parties of the former 'Olive Tree') and the 2008 election-winner 'People of Freedom', a fusion of Forza Italia and National Alliance plus other minor parties. For an overview of the recent changes resulting from the 2008 Italian general election, see Pasquino (2008).

[3] They were mostly telephone interviews performed by a team of interviewers of the Centre for the Study of Political Change (CIRCaP) at the University of Siena.

[4] What is labelled as 'centre-left' in this article refers to those MPs who belong to the following parliamentary groups during the 2006-8 legislature: Communist Refoundation, Italian Communists, Greens, Radical-Socialists, the Olive Tree, Italy of Values, Union of the Democrats for Europe and other smaller components of the centre-left majority. What is labelled as 'centreright' refers to those MPs who belong to the Centrist Christian Democrats, Forza Italia, the Northern League, National Alliance and other small components of the centre-right minority. As for representativeness in terms of parties (here giving the records for the main parliamentary groups), we obtained the following ratios between interviewed MPs and the number of MPs in the lower house: 34.6 per cent vs. 34.5 per cent for the Olive Tree, 21.1 per cent vs. 19 per cent for Forza Italia; 11.4 per cent vs. 10.7 per cent for National Alliance; 6.5 per cent vs. 8.3 per cent for Communist Refoundation; 6 per cent vs. 6 per cent for the Union of Christian Democrats.

[5] For instance, the mean value on the scale from 'unification has gone too far' to 'unification should be strengthened' is 7.7, while the indices of trust in the EU institutions are 5.9 (the EP), 5.6 (the Commission) and 5.5 (the Council).

[6] Such a scale has been created in the following way: individuals having a score higher than 6 in the 1-10 scale of EU institution trust, reaching at least 7 on the question 'unification has already gone too far' to 'unification should be strengthened' and answering 'very much attached to EU' have a score of 3 (high pro-Europeanism). Individuals having a score lower than 6 on the scale of $\mathrm{EU}$ institution trust, answering less than 6 on the question 'unification has already gone too far' to 'unification should be strengthened' and avoiding the answer 'very much attached to EU' have a score of 1 (low pro-Europeanism). All the other cases have a score of 2.

\section{References}

Baldi, B. \& Baldini, G. (2008) 'Italia', in Da Stato unitario a Stato federale. Territorializzazione della politica, devoluzione e adattamento istituzionale in Europa, ed. S. Ventura, Il Mulino, Bologna, pp. $69-112$.

Bellucci, P. (2005) 'La reazione dell'elite politica italiana di fronte all'integrazione europea alla fine degli anni '90', in L'Europa in Italia. Elite, opinione pubblica e decisioni, eds M. Cotta, P. Isernia \& L. Verzichelli, Il Mulino, Bologna, pp. 171-222. 
Benhabib, S. (2002) The Claims of Culture: Equality and Diversity in the Global Era, Princeton University Press, Princeton.

Best, H., Lengyel, G. \& Verzichelli, L. (eds) (2010) The Europe of Elites. A Study into the Europeanness of Europe's Economic and Political Elites, Oxford University Press, Oxford.

Bolgherini, S. (2006) Come le regioni diventano europee. Stile di governo e sfide comunitarie nell'Europa mediterranea, Il Mulino, Bologna.

Brunazzo, M. (2005) Le regioni italiane e l'Unione europea. Accessi istituzionali e di politica pubblica, Carocci, Rome.

Conti, N. (2006) 'Party conflict over European integration in Italy: a new dimension of party competition?', Journal of Southern Europe and the Balkans, vol. 8, no. 2, pp. 217-233.

Conti, N. \& Verzichelli, L. (2005) 'La dimensione europea del discorso politico in Italia: un'analisi diacronica delle preferenze partitiche (1950-2001)', in L'Europa in Italia. Elite, opinione pubblica e decisioni, eds M. Cotta, P. Isernia \& L. Verzichelli, Il Mulino, Bologna, pp. 61-116.

Cotta, M., Isernia, P. \& Verzichelli, L. (eds) (2005) L'Europa in Italia. Elite, opinione pubblica e decisioni, Il Mulino, Bologna.

Dyson, K. \& Featherstone, K. (1996) 'Italy and EMU as a "vincolo esterno": empowering the technocrats, transforming the state', South European Society \& Politics, vol. 1, no. 2, pp. $272-299$.

Fabbrini, S. (ed.) (2003) L'europeizzazione dell'Italia, Laterza, Rome.

Fabbrini, S. \& Piattoni, S. (eds) (2008) Italy in the European Union: Redefining National Interest in a Compound Polity, Rowman \& Littlefield, Lanham.

Fargion, V., Morlino, L. \& Profeti, S. (eds) (2006) Europeizzazione e rappresentanza territoriale. Il caso italiano, Il Mulino, Bologna.

Ferrera, M. \& Gualmini, E. (2004) Rescued by Europe? Social and Labour Market Reforms in Italy from Maastricht to Berlusconi, Amsterdam University Press, Amsterdam.

Giuliani, M. (2006) La politica europea, Il Mulino, Bologna.

Graziano, P. (2004) Europeizzazione e politiche pubbliche in Italia. Coesione e lavoro a confronto, Il Mulino, Bologna.

Gualini, E. (2004) Multi-level Governance and Institutional Change: The Europeanization of Regional Policy in Italy, Ashgate, Aldershot.

Hooghe, L. (2002) The European Commission and the Integration of Europe: Images of Governance, Cambridge University Press, Cambridge, UK.

Maniscalco, M. L. (2006) 'Introduzione', in Tra pace e sicurezza. L'incerta Europa delle élites italiane, ed. M. L. Maniscalco, Franco Angeli, Milan, pp. 9-16.

Mazzoleni, M. (2009) 'The Italian regionalization: a story of partisan logic', Modern Italy, vol. 14, no. 2 , pp. $135-150$.

Morlino, L. \& Tarchi, M. (1996) 'The dissatisfied society: the roots of political change in Italy', European Journal of Political Research, vol. 30, no. 2, pp. 41-63.

Pasquino, G. (2008) 'The 2008 Italian national elections: Berlusconi's third victory', South European Society \& Politics, vol. 13, no. 3, pp. 345-362.

Radaelli, C. \& Franchino, F. (2004) 'Analyzing political change in Italy', Journal of European Public Policy, vol. 11, no. 6, pp. 941-953.

Rokkan, S. \& Urwin, D. W. (1983) Economy, Territory, Identity. Studies in West European Regionalism, Sage, London.

Sartori, G. (2005) Parties and Party Systems. A Framework for Analysis, ECPR Press, Colchester.

Sbragia, A. (2000) 'Italy pays for Europe. Political leadership, political choice and institutional adaptation', in Transforming Europe: Europeanization and Domestic Change, eds M. Green Cowles, J. Caporaso \& T. Risse, Cornell University Press, Ithaca, NY, pp. 79-96. 
Szczerbiak, A. \& Taggart, P. (eds) (2007) Opposing Europe? The Comparative Party Politics of Euroscepticism. Volume 2: Comparative and Theoretical Perspectives, Oxford University Press, Oxford.

Walker, R. (1976) Dal confronto al consenso. I partiti politici italiani e l'integrazione europea, Il Mulino, Bologna.

Christophe Roux is Associate Professor of Political Science at the University of Montpellier I. His research interests are in the field of regional nationalism in Europe. He is a member of the editorial board of Pôle Sud. Revue de Science Politique de l'Europe méridionale. He has edited (with N. Conti and F. Tronconi) Parties and Voters in Italy: The Challenges of Multi-level Competition (Modern Italy, vol. 14, no. 2, 2009).

Luca Verzichelli is Professor of Political Science at the University of Siena. He is the editor of the Rivista Italiana di Scienza Politica. His research interests focus on political elites, budgetary policy and parliamentary institutions. He has authored several volumes, articles and chapters in edited books. His most recent works include: Political Institutions in Italy (Oxford University Press 2007, co-authored with M. Cotta). 